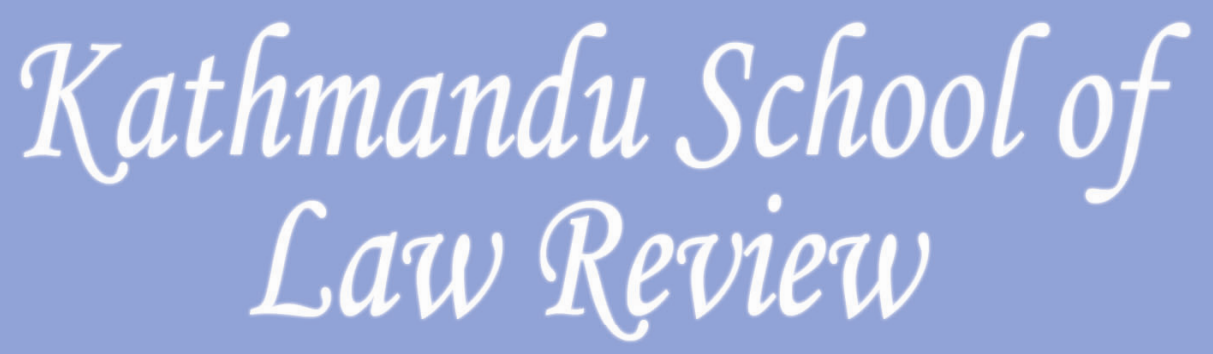

ISSN 2091-2110

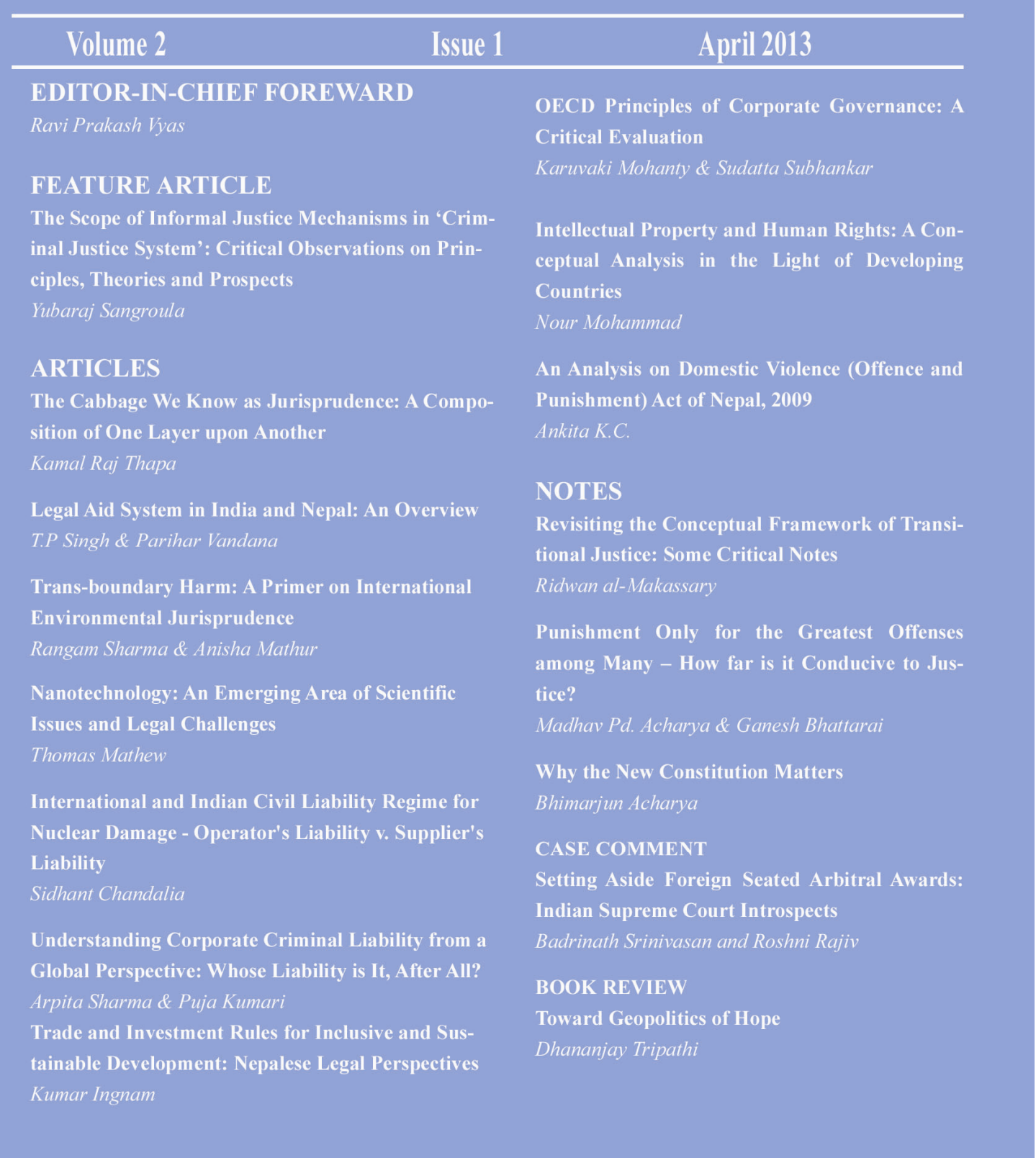




\title{
Revisiting the Conceptual Framework of Transitional Justice: Some Critical Notes
}

\author{
Ridwan al-Makassary ${ }^{1}$
}

\begin{abstract}
Scholars generally agree that transitional justice represents a framework of mechanisms that works to restore the rule of law and justice through both judicial and non-judicial responses. From the outset, transitional justice comprises a broad, complex and elusive conceptual framework. This is necessarily so because the measures to be employed vary from case to case and country to country. Likewise, adopting a mechanism that has been successful in one country will not necessarily achieve the same results in another country, or at another time once and for all. In this perspective, the article attempts to review the conceptual framework of transitional justice. It presents analytical description on transitional justice concerning definition, goals, development and comprehensive mechanisms.
\end{abstract}

\section{Introduction}

Transitional Justice first emerged in the 1990s as an agenda of the international human rights movement. Principally, it is intended to promote and uphold human rights and democracy in post authoritarian regimes and post conflict situations. David Forsythe observes that transitional justice drew international attention by the late 1980s and early 1990s due to the demise of authoritarian regimes in Latin America and the bankruptcy of European communism, followed by social change affecting national and international policies for democracy and human rights ${ }^{2}$. Likewise, Mark Arenhovel argues that the theoretical discourse of transitional justice developed rapidly from the 1980s, mainly concentrating on the regime changes in Latin America ${ }^{3}$.

1 Graduate of Master of Human Rights and Democratisation (MHRD) from Sydney University, Australia and Mahidol University, Thailand (2011-2012) and Researcher at the Papua Peace and Development Action (PaPeDA) Institute, Jayapura, Papua.

2 DP Forsythe, 'Human Rights and Mass Atrocities: Revisiting Transitional Justice' (2011) 1 International Studies Review 13, 85-95.

3 M Arenhovel, 'Democratization and Transitional Justice' (2008) 15(5) Democratization 570, 570-587. 
Similarly, Rosemary Nagy notes that Transitional Justice has emerged as international discourse over the past 15 years, especially with the presence of ${ }^{4}$

... international criminal tribunals, hybrid courts and the International Criminal Court (ICC); the development of a 'right to truth' and 'right to reparation' under international law; the transnational proliferation of Truth and Reconciliation commissions (TRCs); the expansion of Transitional Justice scholarship such that it now has a dedicated journal, research centers and academic programmes; and the birth of international and regional Transitional Justice NGOs

However, some scholars are skeptic about such views. They are of the view that the concept of transitional justice had emerged earlier. Roht-Arriaza argues that there had been concerns about the activities needed following mass atrocities and abuses of human rights in the past ${ }^{5}$. Bass states that after violent conflict between Druze and Christians in the end of nineteenth century the French foreign minister proposed the creation of international commission that would investigate the outbreak of civil war, bring guilty Syrians and Ottomans to book, pay reparations ${ }^{6}$.

Principally, the literatures of transitional justice locate it within a broad, complex and elusive conceptual framework. This paper will examine this framework in an attempt to achieve a clear understanding, making it more accessible to a general audience. It will, therefore, describe and analyze several key concepts, primarily those concerned with transitional justice's definition, goals, development, and comprehensive mechanisms.

\section{Definition of Transitional Justice}

There is no single, universally accepted definition of transitional justice. Louis Bickford states that transitional justice is a link between the two concepts, namely transition and justice'. However, 'Transitional Justice: How Emerging Democracies Reckon with Former Regimes', a weighty anthology of writings edited by Neil Kritz states that the common understanding of it as 'justice during transition' is misleading. Likewise, in an attempt to define transitional justice, Bickford further states transitional justice as a framework for confronting past abuse as a component of a major political transformation in many ways and activities ${ }^{8}$.

Generally, transitional justice can be defined in two ways. Firstly, there is a narrow definition of transitional justice that is associated with upholding human rights after the

\footnotetext{
4 R Nagy, 'Transitional Justice as Global Project: critical reflections' (2008) Third World Quarterly 29, 275-289.

$5 \quad$ R Riazza in Forsythe (n 2) 85.

6 Bass in Forsythe (n 2).

7 L Bickford, 'Traditional Justice Entry' in Encyclopedia of Genocide and Crimes against Humanity (2004) 105-1047.

$8 \quad$ Ibid.
} 
demise of an authoritarian regime. This definition is mainly concerned with judicial responses. Secondly, there is a broad definition of transitional justice that not only emphasizes judicial responses for the protection of human rights after mass atrocities, but also incorporates the non-judicial mechanisms used for handling past atrocities, especially in post conflict situation.

The proponents of narrow judicial response definition explain transitional justice as the view of justice associated with periods of political change, as reflected in the phenomenology of primarily legal responses that deal with the wrong-doing of repressive predecessor regimes ${ }^{9}$.

Going beyond the narrow judicial response definition, Roht-Arriaza in 'Transitional Justice in the Twenty-First Century', defines transitional justice as that set of practices, mechanisms and concerns which arise following a period of conflict, civil strife or repression, and that are aimed directly at confronting and dealing with past violations of human rights and humanitarian law ${ }^{10}$.

Similarly, Michael Humphrey \& Estela Valverde defines transitional justice as being about the recovery of the rule of law and justice after mass violence ${ }^{11}$. In a similar light, Mani ${ }^{12}$ describes transitional justice as restoring justice within the parameters of peace building. Furthermore, she argues for a three-fold view of reparative justice: restoring the rule of law through reforms to prisons, police and judiciary; rectifying human rights violations through trials, truth commissions, reparation and traditional mechanisms; and redressing the inequalities and distributive injustices that underlie war, ${ }^{13}$.

Hence, at one extreme there are narrow definitions of transitional justice as being concerned with judicial responses by post-authoritarian regimes to past atrocities, while at the other extreme broad definitions also encompass non-judicial mechanisms, for example non-judicial reconciliation as a response to human right abuses in post conflict situations. Between these extremes most scholars agree that transitional justice works to resolve past human rights abuses and atrocities by both judicial and non-judicial mechanisms.

\section{Goals of Transitional Justice}

Transitional justice aims to restore human rights, the rule of law and justice in post authoritarian regimes and post conflict situations. The overarching concept here is justice, which can be based principally on retribution (punishment for wrongdoing) or on restoration (the construction of relationships between the individuals and communities).

\footnotetext{
$9 \quad$ R Teitel, ‘Transitional Justice Genealogy' (2003) Harvard Human Rights Journal 16, 69-94.

$10 \quad$ R Arriaza in Nagy (n 4) 277.

11 E. Valverde \& M. Humphrey, 'Human Rights Politics and Injustice: Transitional Justice in Argentina and South Africa' (2008) International Journal of Transitional Justice (Oxford) 2, 83-105.

12 Mani in Nagy (n 4) 277.

13 Ibid.
} 
Retributive justice holds that perpetrators have legal responsibility for their acts, and works by bringing them to the court. Restoration is mainly concerned with trying to find non-legal mechanisms, for example by building relationships and seeking reconciliation.

Colleen McGinn argues that upholding justice through legal mechanisms, especially if it involves punishing perpetrators, should be consistent with the principles of natural justice, and therefore done with fairness ${ }^{14}$. It should never reflect 'revenge' justice. For example, the trial and subsequent execution of Nikolai and Elena Ceausescu in Romania in 1989 could be counted in the category of revenge. It occurred during the uneasy transition towards upholding the rule of law and human rights, when the government still represented the oppressive communist regime.

Sanam Naraghi Anderlini et al. in 'Inclusive Security, Sustainable Peace: A Toolkit for Advocacy and Action' propose that the goals of transitional justice include:

... addressing, and attempting to heal, divisions in society that arise as a result of human rights violations; bringing closure and healing the wounds of individuals and society, particularly through "truth telling;" providing justice to victims and accountability for perpetrators; creating an accurate historical record for society; restoring the rule of law; reforming institutions to promote democratization and human rights; ensuring that human rights violations are not repeated; and promoting co-existence and sustainable peace'. ${ }^{15}$

McGinn states that three considerations need to be carefully reviewed in achieving the goals of transitional justice: legal considerations, ethical considerations, and political considerations.

\section{Legal Considerations}

Legal considerations are critical to transitional justice, especially in the restoration of the rule of law and justice. In practice, one of the challenges is how to reach a delicate balance between the rights of the perpetrators and the rights of victims and families.

Huntington classified three categories of crimes that need to be solved by legal considerations $^{16}$ : crimes against the state, crimes against individuals and crimes of collaboration. Similarly, McGinnexplains that:

14 C. McGinn, 'Transitional justice: International experiences and lessons for Sri Lanka' (2000) 18(2) Ethnic Studies Report, 160.

15 SN Anderlini 'Democracy and Governance' in International Alert, Inclusive Security, Sustainable Peace:

A Toolkit for Advocacy and Action (2004) 1.

16 International Alert (n 15) 160. 
Treason trials are extremely rare, and collaboration frequently fails standards of criminal liability. The vast majority of human rights crimes that are prosecuted are crimes committed by individuals against other individuals. However, proving criminal liability in a context of widespread violence, within a chain of command, or after a long passage of time may be difficult indeed. ${ }^{17}$

Because proving criminal liability can be so difficult, the legal mechanisms of retributive justice should only be implemented after all other considerations have been taken into account.

\section{Ethical Considerations}

In achieving the goal of transitional justice, ethical considerations can become problematic. This is because of the intimate relationship between ethical and emotional responses. For example, while many people were impressed with the success of the South African Truth and Reconciliation Commission, many of the victims did not feel happy.

In the light of above, Braid argues that some victims and their families were disappointed with the amnesty granted to perpetrators ${ }^{18}$. She comments that truth, not justice, is the best that the new South Africa can offer. And many... still find that hard to understand ${ }^{19}$.

Hence, attempting to balance the rights and interests of victims with legal and political considerations can give rise to ethical dilemmas. In reality priority is often given to these legal and political elements. Prioritizing legal and political considerations above moral and ethical issues may lead to dissatisfaction among victims.

\section{Political Considerations}

Political constraint is one of the challenges in applying transitional justice. In practice, these determine what kind of transitional justice should be achieved, as well what strategy should be taken in order to fit with domestic interests, history, and the local context. A country may choose an approach which accommodates these with political interests. For example, in Central and Eastern Europe (with the exception of Romania), the application of transitional justice involved a negotiation between the political elite.

In Latin America, military governments gave amnesties and forgiveness to pave a way for negotiations. However, while transitional justice may bend to accommodate social realities as such, it can also often used as a mechanism to restore formal justice and the rule of law. The path that transitional justice takes is often determined by broad political considerations, and thus these can drive the mechanisms and strategies taken to achieve it.

Ibid.

Ibid 162.

Ibid . 


\section{Development of Transitional Justice}

Ruti Teitel in 'Genealogy of Transitional justice' identified three phases in the development of transitional justice ${ }^{20}$. The first phase of transitional justice began following the Second World War in 1945, with the well-known Nuremberg trials. These trials were associated with interstate cooperation and sanctions. The second phase of transitional justice was democratization and political fragmentation (the third wave democracy). This is exemplified by the collapse of Soviet Union, which in turn led to concurrent transitions throughout much of the world. One example of such follow-on transition is the 1970 withdrawal of Soviet support for guerrilla activity in South America, and the subsequent end military rule.

The third phase of transitional justice occurred at the end of Twentieth Century, characterized by globalization and political instability and violence. This phase is characterized by the emergence of the rule of law as a paradigm in transitional justice. In other words, Teitel states that transitional jurisprudence normalizes an expanded discourse of humanitarian justice constructing a body of law associated with pervasive conflict, which contributes to laying the foundation for the emerging law of terrorism ${ }^{21}$. In this light, I regard the third phase signify the phase of law of terrorism as part of transitional justice framework.

Consistent with the development of transitional justice as an evolutionary process, Bickford identifies a number of landmark events ${ }^{22}$. The first of these include the International Military Tribunal at Nuremberg and de-nazification programs in Germany. The next event, include the trials of former military junta members in Greece (1975) and Argentina (1983). The significant point of these two cases is that domestic judicial systems successfully tried the intellectual actors in past abuses for their crimes. Likewise, establishment of Truth and Reconciliation Commission (TRC) in 1995 at South Africa which aimed to address past human rights crimes is the other event. After that many countries established truth commissions, including East Timor, Ghana, Peru and Sierra Leone. Finally, the last the event includes the creation of ad hoc tribunals for the former Yugoslavia and Rwanda.

Furthermore, Bickford added that while these tribunals not specifically designed to strengthen democratic transitions they have enhanced jurisprudence in transitional justice and achieved some victories for accountability ${ }^{23}$. Here, I regard that the significant contribution of these tribunals has established robust foundations for judicial mechanisms.

Teitel (n 9).

Ibid 71-72.

Bickford (n 7) 105-1047.

Ibid. 


\section{Comprehensive Mechanisms}

Several mechanisms have been used to respond to past atrocities and human rights abuses. As noted above, these can be broadly bracketed into two categories, judicial and nonjudicial.

According to the UN Secretary General's 'Report on the Rule of Law and Transitional Justice in Conflict and Post-conflict Societies (2004) ${ }^{24}$, comprehensive mechanisms: '... may include both judicial and non-judicial mechanisms, with differing levels of international involvement (or none at all) and individual prosecutions, reparations, truthseeking, institutional reform, vetting and dismissals, or a combination thereof.'

The International Centre for Transitional Justice (ICTJ), an NGO which is involved in transitional justice initiatives in over 30 countries, defines the major approaches in its website as: 'prosecution, truth-telling, reparation, institutional reform, promoting reconciliation and social reconstruction, memorialisation and taking into account gendered patterns of abuse. ${ }^{25}$

Similarly, Colleen McGinn categorized these into five broad categories: 'prosecuting crimes against the state (i.e. treason), prosecuting crimes against individuals (i.e. particular acts of human rights abuses), non-criminal sanctions (e.g. banning former elites from holding political office), truth commissions; and doing nothing (amnesties or simply sweeping the whole matter under the rug)., 26

Louise Bickford $^{27}$ and Sanam Naraghi Anderlini et al. ${ }^{28}$ synthesized these comprehensive transitional justice measures under a number of headings which deserve attention and brief discussion following.

Prosecution of perpetrators: This can occur at domestic level, or in a hybrid internationalized court (such as Sierra Leonne's Special Court), or in an international court such as the International Criminal Court (ICC).

Establishing the Truth commission: The best known of these is perhaps South Africa's Truth and Reconciliation Commission (noted above), formed after the collapse of that country's apartheid regime. Its activities included doing historical research, compiling victims' testimonials and recording oral histories.

Establishing reparations policies that take into account the requirements of, or moral obligations, to the victims: These policies include economic compensation as well as a

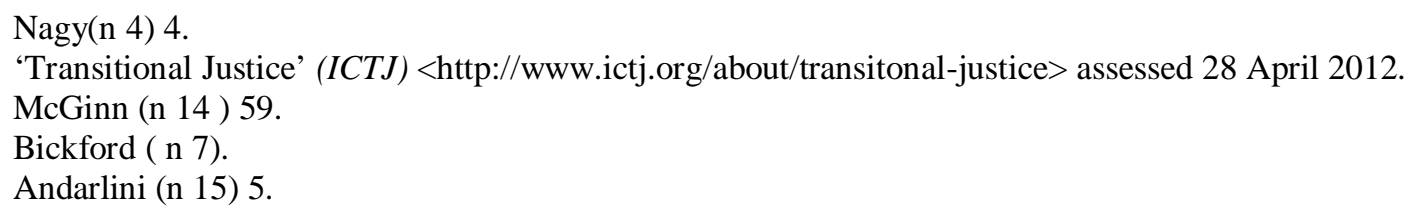


variety of health (physical and mental) and education benefits, and symbolic measures such as a state apology.

Remembering and honoring victim: This can be achieved through a variety of activities, including consulting with victims to develop memorials and museums of memory, converting public space such as former detention camps into memorial parks and interpretive sites, and catalyzing constructive social dialogue about the past.

Developing reconciliation initiatives: Examples of these mechanisms are working with victims to determine what they require in order to experience healing and closure, and creating peaceful coexistence among former adversaries without sacrificing justice and accountability for perpetrators.

Reforming institutions:Institutions that have a history of abusive behaviour need to be reformed. Such institutions may be security forces or the police. Reform is necessary to prevent repeated abuse in the future, as well as to establish relationships based on functioning and fair institutions.

Banning of known human rights violators from holding political office in the new government (Lustration): This is rarely used in transitional justice, and is sometimes part of a Truth Commission's recommendations. In Elsalvador, for example, an ad hoc commission was created as part of the peace agreement in order to examine the activities of military officers during the war. Through its work, and that of the truth commission, 102 officers were 'retired' due to human rights violations perpetrated during the conflict. In Serbia, a lustration law was enacted in May 2003 stating that the records of public officials would be reviewed to know if they had violated human rights; if found guilty, they would be removed from any current office they held and could be banned from working for public office for the following five years.

In sum, all the mechanisms above can be categorized as judicial and non-judicial mechanisms that are important in handling past atrocities. However it is important to note that the way transitional justice is implemented depends heavily on the local context. There can be no single package of measures which can be applied in all cases once and for all. The success story of a transitional justice measure (or group of measures) in one country cannot automatically be applied in another country.

\section{Conclusion}

Transitional justice has principally emerged as an agenda of the international human rights movement to promote and uphold human rights and democracy in the post authoritarian regimes and post conflict situation. Since the early 1990s, it has attracted international attention. Although there is no single definition on transitional justice, scholars generally agree with that transitional justice represents a framework of mechanisms that works to restore the rule of law and justice through both judicial and non-judicial responses. In 
achieving the goals of transitional justice there is a need to consider legal considerations, ethical considerations and political considerations.

From historical point of view, the development of transitional justice can be traced from its post-war beginnings in 1945 (the first phase), through the democratization and political fragmentation of third wave democracy (second phase), to the globalization and political instability and violence that characterized the end of the twentieth century and the beginning of the new millennium (the third phase).

There are comprehensive mechanisms for handling past atrocities, as shown above, however decisions about which of these to implement in any particular country requires careful consideration. In this respect the words of Kofi Annanshould be reiterated. In his influential report 'The Rule of Law and Transitional Justice in Conflict and Post-Conflict Societies' to the United Nations Security Council he reminds us that ${ }^{29}$ :

Success will depend on a number of critical factors, among them the need to ensure a common basis in international norms and standards to mobilize the necessary resources for a sustainable investment in justice. We must learn as well to eschew one-size-fits-all formula and the importation of foreign models, and instead, base our support on national assessments, national participation and national needs and aspirations'.

As noted at the outset, transitional justice comprises a broad, complex and elusive conceptual framework. This is necessarily so because the measures it employs vary from case to case and country to country.

All in all, adopting a mechanism that has been successful in one country will not necessarily achieve the same results in another country, or another time. Transitional justice will only succeed if it acknowledges that every country has its own history, uniqueness, resources and experience.

$* * * * * * * * * * * * * * * * * * *$

29 K. Annan, Localizing Transitional Justice (Stanford University Press 2010). 


\title{
Punishment Only for the Greatest Offenses among Many - How far is it Conducive to Justice?
}

\author{
Prof. Madhav Pd. Acharya ${ }^{1}$ \& Asst. Prof. Ganesh Bhattarai ${ }^{2}$
}

\begin{abstract}
For a proper administration of justice, sentencing policy of any country should focus on both the social security as well as the reformation of the criminal. But in case of Nepal, the former is ignored. Nepalese law states that if a person has committed series of cruel offences, then such person is liable to be punished of imprisonment for the single offence which incurs the longest term for imprisonment. But is this policy justifiable? This paper tries to answer this very question. For that, the authors talk about the present law of Nepal, few cases related with it as well as the Proposed Sentencing Policy Bill 2067 BS (2010 $A D)$.
\end{abstract}

\section{Introduction}

Sentencing policy plays vital role in the administration of justice. Modern justice system claims that the purposes of punishment are reformation of the offender, social security and general deterrence. Among them, reformation of the offender is the most important one. It is on this principle that the offender is given facility to work in the prison, parole release and other concessions of early release. ${ }^{3}$ His/her reintegration in society is the point of focus. If the offender is hard core criminal with criminal records or has committed cruel offenses ${ }^{4}$ more than once and prosecuted once for all, social security becomes prime concern. So,

Professor of Criminal Law and President at Kathmandu School of Law, Nepal

Assistant Professor at Kathmandu School of Law, Nepal

Parole has not yet been part and partial of Nepalese legal system. The concern authorities are reviewing the criminal law and penal policy to introduce it. The Bill of Sentencing Policy 2047 BS (2011 AD) is an example of it. All offenders do not deserve the same term of incarceration is the vital point that has developed alternative to prison system. The alternative to prison system in Nepalese context is very limited. Person committing crimepunishable up to three years of imprisonment may get, at his/her option, converted the imprisonment term into fine with a execution of document that they would go straight in the days to come. The calculation parity is rupees 25 per day Muluki Ain (General Code) 1964 (2020) Chapter on Punishment s 11.

4 Cruel offenders connote those types of offenders who have committed extreme inhuman offenses like rape followed by murder, offenses committed against children, offenses committed against vulnerable groups like sick or aged people or those who have shown brutality in the commission of crime. 
s/he deserves long term punishment reckoning impacts of all the offenses s/he has committed. His/her reformation and early release from jail becomes, generally, points of consideration only at a later stage of his/her prison term. Social security and reformation of offender go hand in hand. Ignoring either of them may be damaging to the society.

\section{The sentencing guideline as per Muluki Ain 2020 Dandasajayeko Mahal (Chapter on Punishment) section 10 and 41}

Mulukin Ain Chapter on Punishment (Dandasajayeko Mahal) deals with sentencing policy of the Nepalese legal system. Its approach is traditional; there is no reference as to the reformation of offenders. Of course, Jail Rule 2020 provides provision that good behaving prisoners may be released from the prison with 50 percent concession as a reward for their good behavior; ${ }^{5}$ even though no specific assessment mechanism exists. This concession provision is being used haphazardly to the possible detriment of the society. In this background, social security seems to be the prime concern of sentencing system in Nepal. Section 10 and 41 of the chapter read together provide that if any offender has committed more than one offense in the same incident (like murder and Dacoit) or if s/he has committed one offense to achieve another criminal goal (like forgery followed by cheating or procurement of citizenship certificate) or if s/he has committed several offenses of similar nature or of diverse nature (like theft, cheating, murder etc.) on different occasion, $\mathrm{s} / \mathrm{he}$ is liable for punishment of imprisonment only of the offense which incurs the largest term of imprisonment. If s/he has committed several offenses of similar nature, $\mathrm{s} / \mathrm{he}$ is to get imprisonment in only one of them and rest offenses are only recorded on his/ her file.

However, if there is fining provision in addition to imprisonment, fine entailed in each of those offenses are added together and the offender pay such compounded fine. Upon failing to pay, s/he may be held liable to a term of four years' imprisonment as per the merit of the case. ${ }^{6}$ This provision is likely to put the court in dilemma specially when the offender has committed petty theft on several occasions and prosecuted once for all.

When one case is already adjudicated by the court pending the punishment term, if the offender is further prosecuted and found guilty, the court has to see which offense incurs greater punishment. If the former offense incurs greater punishment, nothing is to be done about the later conviction. It is only recorded on the file of offender. If the latter offense is the graver one, the court has to connect it with punishment of former case and fix the punishment on later case as per the law dealing with the latter offense. If punishment should be proportionate to the notoriety of the offender and security requirement of the society are our concern, we have to review this policy. Possibility of reformation of the offender may be another ground of consideration.

Jail Act 1964 (2020) s 29.

Muluki Ain 1964 (n 3) Chapter on Punishment s 38. 


\section{Judicial Pronouncement}

There are several cases that reflect situations stated above. Some of them are even prejudicial to the offender.

\section{a. Satya Prasad Sainju v Dayalaxmi ${ }^{7}$}

In this case, Satya Prasad and his associates had committed murder of the woman who was alone in the house, with a view to steal. They were charged with murder and dacoit. They were made to serve punishment in the crime of murder only, as dacoit incurs only six years of imprisonment compared to murder which incurs life imprisonment, that is, 20 years of imprisonment.

\section{b. Madhav Shrestha $v$ Regional court ${ }^{8}$}

In this case, the offender was found guilty of theft committed by him in four different occasions. The court imposed punishment only in the offense which he committed the fourth time. Rest of the convictions were ordered to be recorded only on the file and as such the offender received one year and six months imprisonment plus four years having failed to pay fine levied in each of those offense and the total punishment added up to five years and six months of imprisonment. If the custodial treatment of the offender is calculated cumulatively, he had already served a term of greater period while in custody (one year, three months and eleven days) than what he actually received as punishment. There is no legal provision to compensate him for the additional imprisonment, which what he was legally entitled to.

\section{c. Nirakar Thapa v Kathmandu District court ${ }^{9}$}

The case pertains to theft. The person was tried in two different district courts in the issue of theft which he had committed for the eleventh time against different victims. The court compounded each of these offenses and adjudicated that the accused was guilty for the offense which he has committed for the eleventh time. He received six years of imprisonment and total sum of fine was incurred in each of eleven offenses.

\section{d. Gita Parajuli v $\mathrm{HMG}^{\mathbf{1 0}}$}

This is a unique case different from those described above. In this case, Gita was charged with trafficking of human beings. She faced the trial with judicial custody.

$7 \quad$ Satya Prasad Sainju v Dayalaxmi NLR 1960 ( 2017) (Nepal).

8 Madhav Shrestha $v$ Regional court (1986) in Supreme Court of Nepal, Phaisala Karyanbayan Sambandhama Supreme Court ka Kehi Nirnayaharu (Judgements on Matters of Punishments, Some Decisions of Supreme Court, unofficial trs of the title) (2012) 383.

$9 \quad$ Nirakar Thapa $v$ Kathmandu District Court DN No. 5015 NLR 1993 (Nepal)

10 Phaisala Karyanbayan Sambandhama Supreme Court ka Kehi Nirnayaharu SCB 2012(2069) 421 (Nepal, 1999). 
After four years and eleven months of trial she was found 'not guilty and acquitted.' Before her acquittal, she was charged with another similar case of trafficking. In this second charge, she was found guilty as an abettor and given punishment for a term of five years of imprisonment. She claimed in her writ petition that since she had already served her term in jail totaling four years and eleven months, she deserved to serve only the remaining period of one month. The court rejected this argument and reasoned that section 41 is applicable only on those cases that are connected with conviction, not with acquittal.

\section{e. Surendra Prasad v Nepal Government ${ }^{11}$}

This case is connected with 'cheating and procurement of citizenship certificate.' The accused was found guilty of both these offenses. Both the offenses incurred one year of imprisonment each. The court rejected to compound the offenses and ordered to serve only one year of imprisonment since the punishment term is similar in both of these offenses. Nevertheless, the court compounded the fine.

Going through the cases afore discussed, it can be seen that most of the cases were connected with theft, one was connected with trafficking in human being, and the last case was connected with cheating and procurement of citizenship with forged document. So there might be diverse charges connected with the offender. Adjudication only on the gravest offense ignoring the rest is too much of simplification of the problem of sentencing. The basis is not clear. This provision has nothing to do with social security neither is it connected with deterrence effect and possibility of reformation of the offender. It is time to review this legal provision.

\section{The Purposed Sentencing Policy Bill 2067 BS (2010 AD)}

With a view to reform the criminal justice system, the Draft Criminal Code 2010 (2067), Draft Criminal Procedure Code 2010 (2067) and the Sentencing Bill 2010 (2067) are in the pipeline. Sooner or later it is expected that these laws would come into force. Regrettably, the purposed laws have also repeated the mistakes of section 41 of Muluki Ain, Chapter on Punisment. The Sentencing Policy Bill in section 11 states that the offender may be punished only on that offense which incurs the largest punishment, no matter whether s/he has committed it on different occasion or on the same incident or has committed one offense to achieve another criminal goal.

\section{Conclusion}

Let us make a balance between social security, deterrence and possibility of reformation of the offender. A notorious offender deserves longer term of imprisonment, while petty offenders (such as stealing) deserve to be viewed with compassion, when compelled by

$11 \quad$ Surendra Prasad v Nepal government NLR 20121268 (2069) BS (Nepal). 
economic situation, there is the possibility of repeating the offence again and the purpose of punishment in those cases should be deterrence to keep the particular offender in line. For this reason, it is proposed to confer discretionary power upon the judge to decide whether to compound the punishment or not. Where the offense is of serious nature, the court may give an order to serve the punishment in consecutive order. If the nature of offense including the offense of the offender is not serious, the court may impose punishment to serve on concurrent basis. It is something to be viewed on the merit of each case. Such a complex issue of sentencing cannot be streamlined by a straight forward law as it is now or as has been proposed by the new law.

$* * * * * * * * * * * * * * * * * * *$ 